\title{
РЕКОНСТРУКЦІЯ ІСТОРИЧНОЇ ЗАБУДОВИ ЯК ЗАПОРУКА ПРИВАБЛИВОСТІ МІСТА
}

\section{RECONSTRUCTION OF HISTORIC BUILDINGS AS THE KEY ATTRACTION OF THE CITY}

\begin{abstract}
Верешко О.В., асистент, Ляшук С.В., студент, Сокур Т. Д., студент, Кузьмич В.В., студент (Луцький національний технічний університет), Верешко А.О., студент (Київський національний університет будівництва та архітектури)
\end{abstract}

Vereshko O.V., assistant, Liashuk S.V., student, Sokur T.D., student, Kuzmych V.V., student (Lutsk National Technical University), Vereshko A.O., student (Kyiv National University of Civil Engineering and Architecture)

Анотація. Проаналізовано стан історичної забудови міста Луцька. Визначено основні проблеми реконструкиії історичної забудови. Виявлено основні причини неналежного стану історичних будівель та несвоєчасної їх реконструкиї̈.

Summary. The current state of historic cities in Ukraine has revealed its problem, revealing the maturation of historical and cultural heritage. An important area of preservation of the historical and cultural heritage of cities is the reconstruction and renovation of modern historic cities and the restoration of buildings and structures monuments of architecture, history and more.

To date, the rapid increase in population and the increasing needs of urban population necessitates permanent new construction and the use of historic buildings for housing and commerce. Preserving the most preserved architectural monuments will guarantee greater attractiveness and increase in the number of tourists within the city.

Over the past few decades, Lutsk has been significantly affected by urbanization, the development of which has little concern for the historical features of its architectural heritage. In particular, in the historic city center, rapid growth and modernization are rapidly replacing historical heritage with amorphous, modern and global projects.

Much of the buildings in the reserve are unfit, for example: houses on Bratkovsky and Drahomanov streets, Prizler's house, the building of Lutsk Orthodox Fellowship of the True Cross and others. All of these and other sites in the historic city center need large-scale reconstruction.

The research revealed that a large part of the buildings in the historic part of Lutsk require major reconstruction. However, the reconstruction must be carried out taking into account the group of physical, socio-economic and socio-cultural factors of urbanization. In addition, work on the reconstruction of the historic building should be carried out only with regard to the purpose of the structures, their subsequent use and a harmonious combination with the surrounding buildings. It should be noted that local 
governments have an important role to play in overseeing the reconstruction of historic buildings.

Ключові слова: реконструкиія, історична забудова.

Keywords: reconstruction, historical buildings.

Постановка проблеми. Сучасний стан історичних міст України характеризується наявністю проблем, пов'язаних із збереженням історикокультурної спадщини. Важливим напрямком збереження історикокультурної спадщини міст $\epsilon$ реконструкція та реновація сучасних історичних міст і реставрація будівель та споруд - пам'яток архітектури, історії та ін. У містобудівній практиці застосовується два види діяльності, що пов'язані із реконструкцію:

- реконструкція міст (на рівні планувальної структури вцілому);

- реконструкція міського середовища, що історично сформувалося (як правило на рівні окремих ділянок у центральній частині міста) [1].

У процесі стрімкого розвитку міст виникає необхідність впровадження культури належного ставлення до цінної історичної забудови та збереження історичного середовища. Потрібно зберегти унікальне історико-архітектурне міське середовище, і при цьому створити сучасну міську інфраструктуру, а це можливо лише шляхом вжиття невідкладних ефективних заходів, що пов'язані із реконструкцією історичної забудови.

Аналіз відомих досліджень і публікацій. Проблеми збереження i розвитку історичної забудови розглядало у своїх дослідженнях багато вітчизняних та зарубіжних вчених. Зокрема, дослідженням проблемних аспектів реконструкції і розвитку історичної забудови міст присвячені роботи М. Бевза, В. Кучерявого, Б. Посацького, С. Ревського, О. Рибчинського, Т. Товстенко та ін. [2, 3, 4]. Історико-містобудівним дослідженням міст України присвячені роботи В. Вечерського [5].

Проблемам реконструкції історичної забудови присвячено багато досліджень i за кордоном. Технологічним аспектам реконструкції історичної забудови присвячені роботи М. Хочови, М. Кангара (Словаччина) [6]. Вплив урбанізації на будівлі історичної спадщини міст Індії досліджений у роботі [7].

Формулювання цілей статті, постановка завдання. Головна мета дослідження полягає в розкритті проблем реконструкції історичної забудови. Поставлені завдання: проаналізувати сучасний стан історичної забудови міста Луцька, визначити основні завдання, що мають бути вирішені під час реконструкції; виявити основні причини неналежного стану історичних будівель та несвоєчасної їх реконструкції.

Виклад основного матеріалу дослідження.

Історичне середовище багатьох міст України на сьогоднішній день знаходиться в кризовому стані, та, на жаль, історичні будівлі все рідше 
піддаються реконструкції. На це існують як суб’єктивні, так і об'єктивні соціально-економічні причини, серед них:

- недосконалість нормативної бази. В Україні нормативна база, що стосується реконструкції, дуже обмежена і не досконала;

- незацікавленість держави. В Україні відсутні державні програми, які могли б стимулювати проведення реконструкції;

- нестача коштів. Реконструкція старих будівель $є$ дуже дорогою, а обсяги державного фінансування часто недостатніми [8].

Реконструкція історичної забудови $є$ однією 3 найскладніших та найактуальніших проблем сучасного містобудування, у зв'язку 3 динамічним процесом забудови міста та постійним наповненням i переплануванням районів. На сьогоднішній день стрімке збільшення чисельності та зростання потреб населення у містах зумовлює постійне нове будівництво та використання історичних будівель для проживання та комерції. Наявність максимально збережених пам'яток архітектури стане запорукою більшої привабливості та зростання кількості туристів у межах міста.

При реконструкції історичної забудови підлягають вирішенню такі завдання:

- ефективне використання територій історичної забудови для створення екологічно чистого, комфортного середовища для проживання та життєдіяльності населення;

- збереження й раціональне використання об'єктів культурної спадщини, зон охорони (буферних зон) пам'яток культурної спадщини, історичних ареалів населених місць та історичного середовища [9].

За останні кілька десятиліть Луцьк зазнав значного впливу урбанізації, розвиток якої мало хвилює історичні ознаки архітектурної спадщини. Зокрема, в історичному центрі міста бурхливе зростання та модернізація швидко замінюють характеристики історичної спадщини аморфними, сучасними та глобальними проектами. Самі фізичні характеристики міста, особливо будівель, безповоротно змінюються, і з часом їх загальна картина стане лише пам'яттю, що збереглася в кількох рештках споруд та фотографій.

Забудова старої частини міста Луцька, яка формувалася впродовж багатьох століть, неодноразово зазнавала руйнації і відбудовувалася в новій якості відповідно до історичних вимог, тенденцій тощо. Під час Другої світової війни протягом лютого-липня 1944 року в результаті артилерійських обстрілів і бомбардувань було зруйновано близько 50 відсотків історичної забудови старої частини міста. Оскільки значна частина історичної міської забудови була втрачена, а на їі місці або з'явились нові будинки, окремі з яких не повністю гармонують 3 існуючою забудовою, або ж залишилися незабудовані ділянки. 
3 метою збереження і раціонального використання історичних пам'яток у 1985 році, на території обласного центру Волинської області був заснований історико-культурний заповідник «Старий Луцьк». Він займає практично усю центральну частину міста. У нього входять обхідний i Верхній замки, католицькі монастирі 3 їх багатою історією, жіночі i чоловічі (шарітки, єзуїти, бригідки, домініканці та ін.), синагога, православні Хрестовоздвиженська та Покровська церкви, будинок Косачів, різноманітні музеї. Перлиною заповідника є Верхній замок (або замок Любарта, побудований в 14 ст.).

Значна частина будівель у заповіднику перебуває в аварійному стані, наприклад: житлові будинки на вул. Братковського та Драгоманова, будинок Прайзлерів, будівля монастиря Луцького Хрестовоздвиженського братства та ін. Усі ці та інші об'єкти у історичній частині міста потребують масштабної реконструкції (рис. 1, 2, 3).

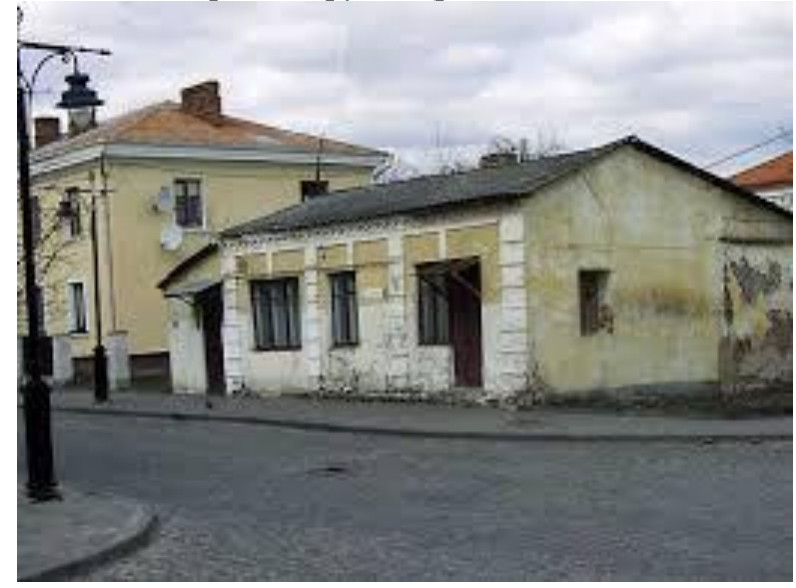

a)

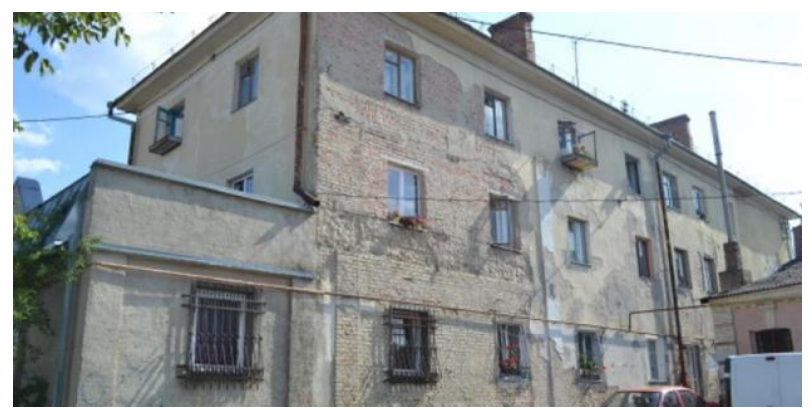

б)

Рис. 1. Фотофіксація стану житлових будинків по вул. Братковського (а), та вул. Драгоманова (б). 


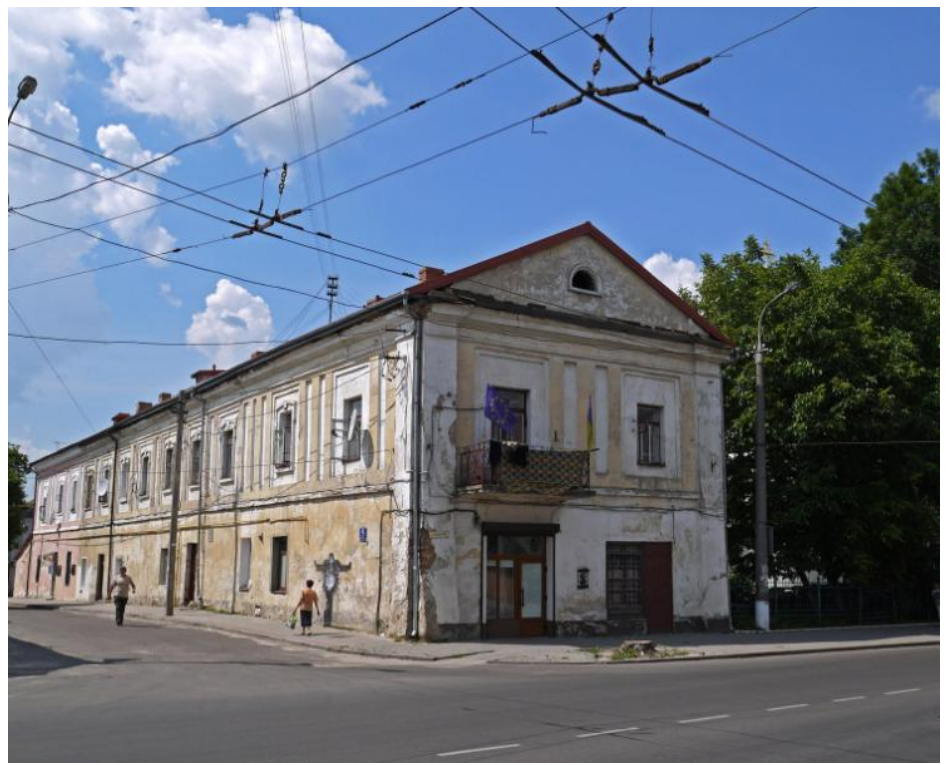

Рис. 2. Будівля монастиря Луцького Хрестовоздвиженського братства

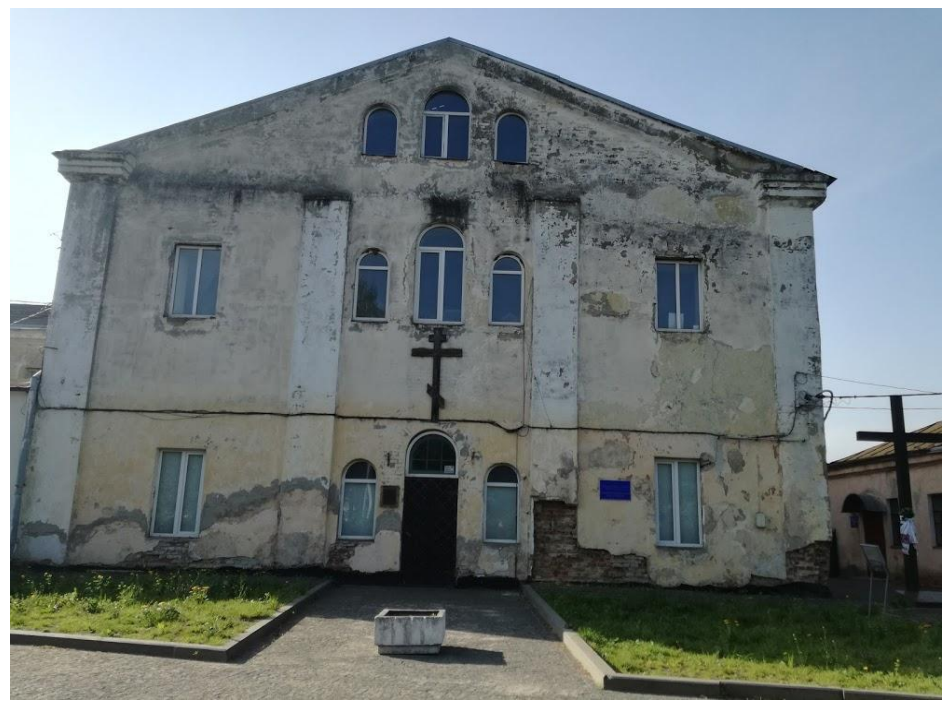

Рис. 3. Будівля монастиря бригідок

Дослідження практики реконструкції історичної забудови міст нашої держави показує, що для якісного поліпшення своєрідності населених міст необхідно на основі глибокого наукового аналізу проводити комплексне 
виконання таких завдань: генплан-проект детального планування, проект реставрації чи реконструкції, проект пристосування чи нового будівництва $[4,10]$.

Тому, працюючи над програмою розвитку міста Луцька важливо зосередити увагу на історичній архітектурній спадщині та іiі характерному впливі на соціокультурне життя міста, щоб максимально зберегти його спадщину.

Висновки. У результаті проведеного дослідження виявлено, що значна частина об'єктів забудови у історичній частині міста Луцька потребує масштабної реконструкції. Однак реконструкцію необхідно проводити іх врахуванням групи фізичних, соціально-економічних та соціальнокультурних факторів урбанізації. Окрім цього, роботи по реконструкції історичної забудови необхідно проводити лише із урахуванням призначення споруд, їх подальшого використання та гармонійного поєднання із навколишньою забудовою. При цьому важливу роль повинні відігравати органи місцевого самоврядування у контролі за проведенням реконструкції об’єктів історичної забудови.

\section{References}

1. Hlazyrin, V.L., Shkrabyk, I.V. Hradostroytel'naya rekonstruktsiya ta renovatsiya istorychnoyi sredy mist // Arkhitekturnyy visnyk KNUBA. - K.: KNUBA, 2016. - № 8-9. [Elektronnyy resurs]. - rezhym dostupu: http://mx.ogasa.org.ua/handle/123456789/3864

2. Bevz M.V. Metodolohichni osnovy vyroblennya ta reheneratsiyi zapovidnykh arkhitekturnykh kompleksiv istorychnykh mist Ukrayiny (na prykladi Zakhidnoyi Ukrayiny): Avtoref. dys. d-ra arkh. 18.00.01 / KHDTUBA. - Kharkiv, 2004. - 32 s.

3. Prostir mista i mis'ka kul'tura (na zlami XX-XXI st.) [Tekst] / B. S. Posats'kyy; Natsional'nyy un-t «L'vivs'ka politekhnika». - L. : Vyd-vo NU «L'vivs'ka politekhnika», 2007. - 208 s.

4. Parasiyk B. Monastyr Svyatoyi Brygity u Luczku. Propozyciya rekonstrukciyi ta renovaciyi / Bogdan Parasiyk, Oleg Rybchynskyj, Sergii Synii // Mizhnarodna naukova konferenciya "Kreatyvnyj urbanizm", 24-25 travnya 2013 roku: tezy dopovidej [vidpovid. za vyp. G.P. Petryshyn] - Lviv: Vydavnycztvo Lvivskoyi politexniky, 2013. S. 106-107.

5. Vechers'kyy V. Skhidna mistobudivna diyal'nist' Ukrayiny: Teoriya i praktyka istoryko-mistobudivnykh pam'yatok naselenykh mists'. - K.: NDITIAM, 2003. - $560 \mathrm{~s}$.

6. K.Kiruthiga, K.Thirumaran. Effects of urbanization on historical heritage buildings in Kumbakonam, Tamilnadu, India // Frontiers of Architectural Research. Vo. 8, Issue 1, March 2019, Pages 94-105. https://doi.org/10.1016/j.foar.2018.09.002

7. Marta Hočová, Marek Cangár, Silvia Bad’urová. Technological Aspects of Reconstruction of Historical Buildings // Procedia Engineering. 2015. Vol. 111. P. 302310. https://doi.org/10.1016/j.proeng.2015.07.093

8. Vladymyrova M.S., Ryzhkova V.O. Rekonstruktsiya istorychnoho tsentru mista yak elementiv stratehiyi rozvytku // Molodyy chas. - Kherson: Hel'vetyka, 2017. - №4 (44). S. 626-629.

5. DBN B.2.2-12: 2019. Planuvannya ta zabudova terytoriyi. - K.: Minrehion Ukrayiny. - 2019, - $185 \mathrm{~s}$. 
9. DBN B.2.2-12: 2019. Planuvannya ta zabudova terytoriyi. - K.: Minrehion Ukrayiny. - 2019, - $185 \mathrm{~s}$.

10. Lesyk-Bondaruk O.O. Mistse ta vbyvstvo monastyrs'kykh ansambliv m. Luts'k u sferi mis'koyi zabudovy // Visnyk Prydniprovs'koyi diyal'nosti akademiyi budivnytstva ta arkhitektury - 2017, № 2. S. 108-113

\section{Список використаної літератури}

1. Глазырин, В.Л., Шкрабик, И.В. Градостроительная реконструкция и реновация исторической среды города // Архітектурний вісник КНУБА. - К.: КНУБА, 2016. - № 8-9. [Електронний ресурс]. - режим доступу: http://mx.ogasa.org.ua/handle/123456789/3864

2. Бевз М.В. Методологічні основи збереження та регенерації заповідних архітектурних комплексів історичних міст України (на прикладі Західної України): Автореф. дис. д-ра арх. 18.00.01 / ХДТУБА. - Харків, 2004. - 32 с

3. Простір міста і міська культура (на зламі XX-XXI ст.) [Текст] / Б. С. Посацький ; Національний ун-т «Львівська політехніка». - Л. : Вид-во НУ «Львівська політехніка», 2007. - 208 с.

4. Парасюк Б. Монастир Святої Бригіти у Луцьку. Пропозиція реконструкції та реновації / Богдан Парасюк, Олег Рибчинський, Сергій Синій // Міжнародна наукова конференція "Креативний урбанізм", 24-25 травня 2013 року: тези доповідей [відповід. за вип. Г.П. Петришин] - Львів: Видавництво Львівської політехніки, 2013. - С. 106-107.

5. Вечерський В. Спадщина містобудування України: Теорія і практика історико-містобудівних пам'яткоохоронних досліджень населених місць. - К.: НДІТІАМ, 2003. - 560 c.

6. K.Kiruthiga, K.Thirumaran. Effects of urbanization on historical heritage buildings in Kumbakonam, Tamilnadu, India // Frontiers of Architectural Research. Vo. 8, Issue 1, March 2019, Pages 94-105. https://doi.org/10.1016/j.foar.2018.09.002

7. Marta Hočová, Marek Cangár, Silvia Bad’urová. Technological Aspects of Reconstruction of Historical Buildings // Procedia Engineering. 2015. Vol. 111. P. 302310. https://doi.org/10.1016/j.proeng.2015.07.093

8. Владимирова М.С., Рижкова В.О. Реконструкція історичного центру міста як елемент стратегії розвитку регіону // Молодий вчений. - Херсон: Гельветика, 2017. - №4 (44). С. 626-629.

9. ДБН Б.2.2-12:2019. Планування та забудова територій. - К.: Мінрегіон України. - 2019, - 185 с.

10. Лесик-Бондарук О.О. Місце та роль монастирських ансамблів м. Луцьк у системі міської забудови // Вісник Придніпровської державної академії будівництва та архітектури - 2017, № 2. С. 108-113 